\title{
Mitigating Production Practices and Antibiotics Use in Meat Industries Prone to Economies of Scale by Institutional Novelties, Marketing and Voluntary Actions
}

\author{
Ernst-August Nuppenau ${ }^{1}$ \\ ${ }^{1}$ Department of Agricultural Market Analysis, Justus-Liebig-University, Giessen, Germany \\ Correspondence: Ernst-August Nuppenau, Department of Agricultural Market Analysis, \\ Justus-Liebig-University, Giessen, Germany. E-mail: Ernst-August.Nuppenau@agrar.uni-giessen.de
}

Received: January 27, 2015 Accepted: March 17, 2015 Online Published: April 21, 2015

doi:10.5539/jfr.v4n3p162 URL: http://dx.doi.org/10.5539/jfr.v4n3p162

\begin{abstract}
Achieving improved standards in animal husbandry (including less use of antibiotics) through appropriate interventions has become a matter of public concern. It is currently both, hotly debated and a challenge for food economics. The question is: how can one achieve change in a given environment of property rights and interests? This paper offers a novel approach intended for conflict solving in meat industries which are prone to economies of scale, which are under international and competitive pricing and which experience structural change. In particular, in case of: (i) economies of scale favouring large-scale production and high stocking densities (supported by increased antibiotic use), (ii) political power about resistance to regulate (avoiding strong interference), but also in contrast to (iii) consumers' wishes and willingness to pay (WTP for a change in production modes), there is a problem of coordination and institutions. In this article, the issue is delineated as a problem of political bargaining and creating marketing channels (broker and agency) which shall actively pursue promotion of reduced antibiotics use (specifically through reduced stocking density) as well as negotiations on compensations (for cost increase). Producers are outlined with regards to scheme participation along willingness to accept (WTA). Stocking density reduction is used as proxi for more healthy animal rearing methods. We establish interest functions and show how a bargain can be modelled in the tradition of Zusman's political economy. Bargaining involves power coefficients for brokerage (premium sharing) as well as an agency (called FSA); the agency is modelled as a bureaucracy optimizing modified costs and benefits. In fact, the agency maximizes its budget and ensures participation of willing producers to join programs. Finally we refer to ways how to solve the issue in modes of political economy models. The assumption is that asymmetric information prevails and consumers are willing to pay (WTP) for healthy food.
\end{abstract}

Keywords: food safety, market segmentation, contracting for antibiotic reduction, political economy model, bargaining model

\section{Introduction}

Recently intensified discussions on the use of antibiotics in animal production reveal a huge problem of market coordination in meat production of countries of concern (for instance in Europe/Germany this has recently reached mass media: Die Zeit, 2014, and bans are requested). Before, the problem had already resulted in many proposals such as: labelling, consumer enlightenment, ban on "industrial farming", etc. (again on the debate in Germany see: TAZ, 2013). However, most initiatives never went really through. Depending on interests the case is usually portrayed differently by lobbying groups, apparently as in a political game. We might realize that the case was put forward on many grounds (health, welfare, property rights, etc.; even philosophical), but limited actions occurred on the side of the public (government) and interventions are marginal (only minimal standards passed). For example, again in Germany, a law was passed which is deemed to regulate; but does not forbid antibiotics (only set minimal rules: TopAgrar Online, 2013a). In contrast public concern increases. Hereafter, pressure is big and the conflict escalates. An exception for relaxation of conflict seems to be a voluntary compromise on animal welfare which is, though not directly addressing human health, linked to advances in changes of practices. It also applies a payment scheme for compensation of costs incurred (Deutsche Bauernkorrespondenz, 2014 on Tierwohl: for instance, a recent statement, TopAgar online 2015, says that 4 Euro-Cent/kg will be collected by retailers from consumers and 64 million Euros will be offered to farmers for changes in practices). 
Such willingness to find options for practice change shows fears of agribusiness for bans. Yet, in the opinion of authors there is an open debate on governance, institutions and marketing novelties. The aim of the paper is to describe such a novelty, imbedded in market segmentation.

First we have to understand the issue in a broader frame of technologies, economics, strategies, politics, and social science. To start as observation: by different strategies such as prophylactic application vs. illness related application of antibiotics (in detail) as well as modern vs. traditional husbandry (in general) farmers try to solve problems in production (animal health), minimize costs (use economies of scale), and become competitive instantly; instead "no use of antibiotics" needs real incentives. For large-scale intensive farming an association between antibiotics use and farm size was suggested as early 2002 (Tilman, Cassman, Matson, Naylor, \& Polasky, 2002). Recently (Fels-Klerx, Puister-Jansen, Asselt, \& Burgers, 2014) investigated this association and they confirmed in multiple regressions that those farming systems associated with size have a problem in antibiotics use; though density is giving a spot with other factors. As it was found a wide range of dosage exists; some farms are more prone to use more antibiotics and these farms seem to have hygiene problems. Yet, about technologies this is associated with economies of scale and it determines success.

Second to describe novelties one has to refer to theoretical concepts and economic practices jointly. From an economic point of view institutions such as markets should optimize allocation, but also solve conflicts and minimize transaction costs (Coase, 1960). Actually the problem might be better described by: what is an appropriate level of antibiotics as external effect and how to get it by right setting. Then a theoretical solution would be to calculate approximately a social optimum and balance costs and benefits (here willingness to pay WTP of health vs. low meat prices for consumers). Such solution requires a full set of property rights and finding markets including pricing of externality. A crucial thing is: are consumers WTP for change in meat production and do technologies exist? It seems, yes, there is WTP to change as comparable studies show for beef (White \& Brady, 2014.) Then a broader conceptual work on producers' willingness to accept (WTA) is needed and markets (actions) for change (options) have to be investigated (Lusk \& Norwood, 2012). But, why does it not work? Market failure seems to prevail and property rights are incomplete (yet "market failure" might be only proved for some aspect: Carlson, Frykblom, \& Lagerkvist, 2007; and it is a general problem). Precisely, deliberations on complex institutional options are missing. (In contrast, it seems that simple interventions are suggested which shall force farmers to modify animal husbandry without cost recognition and this failed). As a political will which may suggest strong industry regulations is lacking (rights with consumers), a "first best" economic solution is far away; it lacks support. So, is there a second best alternative? We think that there is and we will discuss an option based on institutional change imbedded in the theory of bargaining (Zusman, 1976).

Third, for such option imbedded in institutional change we must assume: rights to technologies (antibiotics, stocking, animal health, etc.) are with producers. This seems to be current political practice. In fact, in accordance with the law (whatever volumes of different substances, antibiotics farmers have access to antibiotics under supervision of veterinarians) standards seem to be low in consumers' eyes. (They only claim a right to health). So no solution seems to exist, which serves all parties and which is Pareto superior presuming consumers claim health as right without payment. In contrast there is meat without antibiotics; but is expensive. Looking for such meats (i.e. 100\% healthy given by practices, low stocking, which ought to be achieved for health, though costly), those market shares are low. Privileges are with farmers. Most consumers are not buying this meat and this is considered a problem Requillart and Soler, 2014). A survey in Germany showed: $83 \%$ of chickens received antibiotics at least once (Top-Agrar, 2012). Even, if this is a question on technology, it is also on competiveness because farmers with modern technologies strongly dependent on economies of scale.

Even if it is problem of technology and information, another problem appears at market and public level by giving bad images to meat. As standard argument (raised in public for example by "Food Watch", a lobby group see: PEW 2009) we hear about a necessity to regulate whole production ("no industrial food") as panacea; i.e. regulations through controlling sizes and practices on antibiotics by an authority (governance) are wanted. But what are the underlying assumptions? In economic terms, it could be assumed that consumers/citizens are informed and it depends on WTP to get rid of antibiotics and control stocking indirectly. Though there is evidence on consumers' concerns, assessments of animal welfare, stocking density and antibiotics (Vanhonacker, Verbeke, Van Poucke, Buijs, \& Tuyttens, 2009) as well as WTP (specific for food attributes, health claims sustainability of meat production: Lee et al. 2014) action is lacking. Yet ago, questions of market failure were raised with respect to consumer information on antibiotics use (Carlson, Frykblom, \& Lagerkvist, 2007).

Fourth, with regards to WTP behind doors, why is the industry so much in favour of industrial production, in favour of no-change and does not capitalize WTP (Deutscher Bauernverband, 2013)? Perhaps it is because of fear and power? As opponents of industrial production mostly base arguments on externalities (human health, 
animal welfare and environmental effects: see Meat.Org, 2013 on practices/opinions), producers do not want to surrender. At the other hand to ignore arguments of the industry for income and survival is also not realistic; it is fairly plausible that front lines exist. To recap, there is a fight about interests and how to solve it?

The author suggests: novel institutions could make a difference and solve partly the conflict. Especially by introducing new intermediaries creating incentives and reaching participation of, at least, parts of industry in terms of voluntary agreements, a perspective is opened. This perspective is grounded in contracting. For that we offer bargaining as modelling. In order to be successful in finding innovative solutions, mechanisms (Rausser, Swinnen \& Zusman 2011) have to be anticipated and understood as well as the bargaining modelled. In this regard the aim of this paper is to delineate the issue from a point of bargaining theory (Zusman, 1976); and a power-interplay is presumed as well as measuring and modelling it. Further we follow Requillart and Soler (2014) about classified policy interventions and refer to supply side options on changing the market environment for getting healthier products. Especially since options for differently "controlled" markets are lacking, novelties for health payments are offered which means an indirect market on health. In particular the institution of "broker" and "agency" are proposed beside government interferences and their roles prescribed.

The paper is organized in six sections. (i) We examine the issue of antibiotics use and explain how it should be linked to farm practices, mainly stocking density. (i) The issue of finding institutions is explained by examining the background given economies of scale and intervention options. (iii) The conceptual framework is explained. (iv) I.e. positions for bargaining are delivered and (v) this is mathematically done. (vi) Finally we venture in a short description what is meant by bargaining? We start with the background giving first issues and then ideas.

\section{State of the Art in Antibiotic Evidence and Problems in Meat Industries}

For finding solutions we have to dig deeper into the problem. But, this paper neither intends to present a scientific review on the problem of antibiotics in animal production nor it offers a proof regarding correlations between antibiotics, animal health and farm practices. Our arguments are economic, are based on specific evidence and are as follows: Yet, at the level of science, one can say (also from a human health perspective) that there is preliminary evidence on resistance to bacteria and use of antibiotics in animal husbandry which suggest a precaution in farm practice. In conjunction to production practices, in the meat industry, there was concern already quite early (for agriculture see: Alanis, 2005 and for feed adds specifically: Wegener, 2003), here at micro-biology level. (This goes even further where scientists are now looking at antibiotics in soils and relate crop contamination to practice: Torre, Iglesias, Carballo, Ramírez, \& Muñoz, 2012). At national levels recent studies (Chantziaras, Boyen, Callens, \& Dewulf, 2013) using ranking methods of countries suggest statistical evidence for resistance for animals, also taking farm sizes and stocking density into consideration. To become particularly practical on negotiation terms: a focus is almost at all times on stocking density. Though at the level of correlation between microbiology and animal husbandry, there seem to be a complex story of animal health, antibiotics, hygiene and husbandry (i.e. stocking density, in agronomy, bacteria growth, animal stress and husbandry), such issues have led to recognition of stocking density as a pivotal parameter in industry. (Admittedly besides other practices to control diseases: see Archie \& Theis; 2011, and on stocking density: Estevez, Andersen \& Naevdal, 2007). Generally speaking there is a request to bridge the flaw between health, animal welfare (Soerensen \& Fraser, 2010) and productivity (Rushen, 2003) by reducing stress (stocking, i.e. looking for better production modes).

Likewise at public level citizens look (ask) for better standards in production (lower stocking density). Farmers shall give more space to animals and improve health, but this comes at costs (lower productivity and hence lower competitiveness) for the industry. Producers think they can produce in whatever mode arguing for costs. In the language of property rights (Coase, 1960) they argue for lowest costs and additional costs due to changes in practices should be transmitted to consumer (to get efficiency in antibiotics is not their aim). But do we have a spontaneous market for citizen preferences for reduction and farmers acceptance? The author thinks: no. Remarkably, WTP analyses on labels should show concern of consumers about animal welfare (Loo, Caputo, Nayga, \& Verbeke, 2014), but no effective payments exists. In that regards it is not only a debate on "science", but also on conflicting issues and consumer vs. producer interests. Many such articles (Carlson, Frykblom, \& Lagerkvist, 2007) have been written on preferences and opinions of citizens about animal (welfare), health, rights and farming modes. What do they tell us? In particular stocking density plays a role. An example is the paper of Vanhonacker, Verbeke, Van Poucke, Buijs, and Tuyttens (2009). They wrote about animal welfare and industries' responsibility. Work on badly treating animals (high stocking) has gained much attention (Goodwin \& Shoulders, 2013) asking for rights beyond farmers' rights. Here labelling comes in, but rights are with farmers; they do not want to change things! Labelling (effective for WTP) is requested as tool; but with no market segmentation it is difficult (Tonsor \& Wolf, 2011); how to target money? Labelling requires market segmentation. 
But is segmentation enough to make consumers confident? Yes, if we take stocking, this offers scope for agreement. Stocking may concern animal welfare per se!

As another observation: to a certain extent public discussions mostly end up with requests for specific bans on sizes of farms. As Deckers (2010) argues, the issue is again farm practice. In that respect it has been found that consumers put high premiums on banning big industry (Lusk, Norwood, \& Pruitt, 2006), i.e. specific forms of highly stocking animals in large stables. But this is questioned by industry opinions (Bauernverband, 2013; and for moderate versions see Ngapoet al., 2004). Preferring market segmentation is an option, again. Citizens may decide on limited banning (producers with very high stocking). Admittedly, to come out of that corner there are yet initiatives of the industry as mentioned (TopAgrar, 2013b) looking at meat market segments: (i) no control, (ii) "minor control" (stocking), and (iii) premium.

Finally, if we proceed, we have to address the issue of stocking density and see antibiotics from the point of efficiency and competitiveness. At farm level, modern technology, technical efficiency and economies of scale are crucial performance indicators. In particular, economies of scale are well documented. Many papers argue that modern, large farms are more efficient than small ones (Ollinger, MacDonald \& Madison, 2005), and no return please. Work on economic performance, looking at industry level, supports this view that stocking density is in particular important for business feat (Oude Lansink \& Reinhard, 2004). To summarize, farmers in meat industries are reluctant to change technologies (stocking density), insist on public-private partnerships and strongly depend on current technologies as competiveness is concerned. Change shall not threaten competitiveness (Seals, 2012) and without compensation no change!

\section{Reasons for Market Failure, Background, Institutional Innovation and Governance}

\subsection{Market Failure}

Then we can go even deeper in the reasons for market failures and we should firstly ask: why is the market no solving the problem of antibiotics, though segmentation and labels are suggested; secondly why are there no spontaneous institutional innovations yet and thirdly what are appropriate suggestions fitting in a framework of market failure and politics, as well as how do consumers see it (Korzen, Sandoee, \& Lassen, 2011)? The author thinks there is a lack of institutional innovations because of blocking beyond pure market failure. Generally, institutional innovations are supposed to promote exchange (noticeable under uncertainty) at low costs and they should channel WTP of consumers for health concerns to WTA of producers for actions requested. This requires trust, contracts and coordination. The opposite persists if there is no will for contracting and coordination by participants. In cases of conflict no communication, no deals, and not finding solutions are preferred (missing cooperation and contracts); these are indicators of market failure and policy quarrels (Rausser, Swinnen, \& Zusman, 2011).

In contrast, in theory (i.e. in cases of aiming at self-explained solutions - as example see principal-agent concepts or incentive schemes inter alia: Furubotn \& Richter, 2005) - we have instant actions/service taken by intermediaries. For instance a broker steps in in case of market search. To transfer the idea, in our case a "service" would be antibiotic reduction and a "payment" (WTP, compensation) for quality meat without antibiotics can solve the problem. How should it be organized? In particular, we see our task in increasing numbers of institutional choices by suggesting brokers and an agency as contracting units. Brokers sell meat at a certified level of no antibiotics and agreed lower stocking density. Likewise, an agency (here a "Food Safety Agency" FSA: using compensation for industry's efforts to use lower antibiotics and stocking density) may bargain on reducing density at a flexible/bargain rate. Then we have different meat markets. In result it means splitting markets. Such a suggestion may create tensions in beginning, but from an analytical viewpoint institutions of a broker and an agency are innovative choices, creating incentives and cooperation, as will be shown. How to do it?

\subsection{Alternative Institutions}

For a short introduction: for brokers, the description seems to be easy (see below), because they can promote meat of high quality directly referring to quality meat without antibiotics. In this paper it is assumed that brokers can create trust (Lindgren, 2003). However, it is not discussed how this works out, rather we take the position that it is costly and the broker and retailer system will do only the job if a margin can be realized. For further literature on modes to create trust, farmers' assurance we refer to discussions on the role and perspective of the meat industry (Bailey \& Garforth, 2014) as well as we are fully aware that consumer trust vs. mistrust are complex issues in the meat industry (perhaps we cannot address them here: Eden, Bear, \& Walker, 2008). There might be big problems of disease management (Garforth, Bailey, \& Tranter, 2013) and it is assumed that QS (in Germany) is one response. However again, it is not the intention of this paper to qualify who is doing better broker/retailers of the agency/QS? Rather we want to explore the costs and benefits as well as option to get a 
coordination mechanism along market segmentation and brokers and an agency/QS competing for consumers WTP in different market segments. Hereby the quality (food with no antibiotics) is exogenous for the broker, but endogenous to QS (subject to negotiations on stocking density of animals and antibiotics use).

For the agency, the task assignment is more complicated. Such an agency can negotiate with industry members on terms of conduct (farm practice in particular), and cost compensation (in general). Compensations could come from health insurance companies which act on behalf of citizens' WTP for safer food. The agency is needed as a competitor to redirect brokerage or else we are stuck as presently observable by blocking. A suggestion is: government establishes a semi-autonomous agency (FSA for instance "QS" in Germany, but with competence, money and power: QS, 2013a). We will model the agency as an entity inspecting production parameters (such as stocking density of animals linked to antibiotics) and assures correct practices. The suggested concept departs from a simple minded version of governing quality and health of food in the meat sector through checks and control of a public authority. It rather works with a hybrid system of minimal standards (on antibiotic use in terms of state control of veterinary regulations) and private sector institutional innovations which are partly financed by health insurance units.

\subsection{Governance and Institutions}

Our underlining issue for governance is: yes, the government can set production standards; but who controls them, what are the control costs (for the public)? For this we seek solutions which are more cost effective that public control of each and any farm. Additionally we work with the Coase (1960) perception that "good" governance is to set rights which are tradable (see below); rather than to assign the burden of health control directly to the government which would mean spending a lot taxpayers' money. We assume there is a WTP for health, but the question is how to "optimally" channel that money to agencies which are working on participatory grounds with the industry and by that "minimizing" transaction costs.

Actually the objective of the paper is not to make simple suggestions; rather we need to delineate complex interest functions and show how practices (technology standards on antibiotics) can be endogenously derived (negotiated, here based on correspondingly agreed criterions (stocking density). These standards can then be linked to marketing and governance. In fact, we will show how to develop an economic bargaining concept (model) which enables mutual contracting on parameters and spells out industry performance (Zusman, 1989). As will be shown, particular modifications to a Zusman model shall suit already contracting in meat industry. Also, reference points for bargaining to find optimal parameters must be mentioned.

On procedures: we (i) delineate explicitly novel options as derived from the institution economic theory of Zusman (1989) who proved that trust can be with brokers and agencies in agrarian societies which are serving different roles as middlemen for revenues, (ii) we show consequences for health and (iii) say what might be accepted. It is against this background that we (iv) will discuss innovation through explaining normative choices for redesigning institutions, opening up bargains on indirect terms (stocking density). (v) Options for farmers (on stocking) imbedded in institutions offer improvements for both sides (be Pareto superior); in particular a negotiation platform is discussed. Improvements are to be recognized at physical level as reduced application of antibiotics (health), but also at financial and welfare levels (gains for consumers: WTP, and producers: profits plus WTA); and costs (competitiveness) of the industry matter (farmers and processors seek viability). On governance, it has to be mentioned, that, in a tradition of self-regulation, the suggested concept is restrained to voluntary bargaining of agents in industries. The government, as said, is not directly involved, though minimum standards are introduced and we get a hybrid in governance. But no game with government is modelled. Actions to be taken are voluntary; and it can be tested how a set of rights set by government (as standards) contribute to results. For that task references of cooperation and defection are to be stated (below). We stick to a concept of minimal governance.

\section{Concept and Framework}

In this chapter we will explain our conceptual framework. It is based on the notion of co-existence of economies of scale in meat production with modes to encourage reduced stocking as well as to create markets for better "quality" meat. Hereby we follow the above problem statement. The assumption is larger farms with high stocking show higher infection risks, they want high compensation, and better prices are needed to receive participation in antibiotics reduction. There is a trade-off between size, density and antibiotics. It has been said before, large farmers will immediately deny this (actually to defend themselves); but we work with indications and options which constitute the conflict for which we seek solutions and negotiation.

We start with a depiction of economies of scale and stocking density (Diagram 1: for mathematical outline see next chapter). The argument is: average costs are currently low because of economies of scale and high stocking 
densities. Because of the fact that antibiotics are almost free in use (though minimum standards must be recognized and veterinarians are involved) high stocking densities in the industry are feasible. By use of high antibiotics, though at legal limits, assure animal health. A reversal requires compensation, i.e. average costs and marginal costs are to be related to application (control) of antibiotics and technology. This means in absence of or in case of low antibiotics, given a certain size of the operation, additional costs accrue because of additional hygiene measures, etc. Please note this is not a criticism of industries, rather an observation of industries typically aiming at low costs in competition. Such reality is linked to missing opportunities for market segmentation (i.e. higher prices, WTP, for meat with no antibiotics in production; higher costs cannot be transmitted, etc.). Later, average and marginal costs are linked to pricing in market segments. Note, as usual in marketing analysis (Zusman, 1989) we are here not interested in changing farm structures, rather our focus is looking for marketing mechanisms and controlling animal density in terms of institutions.

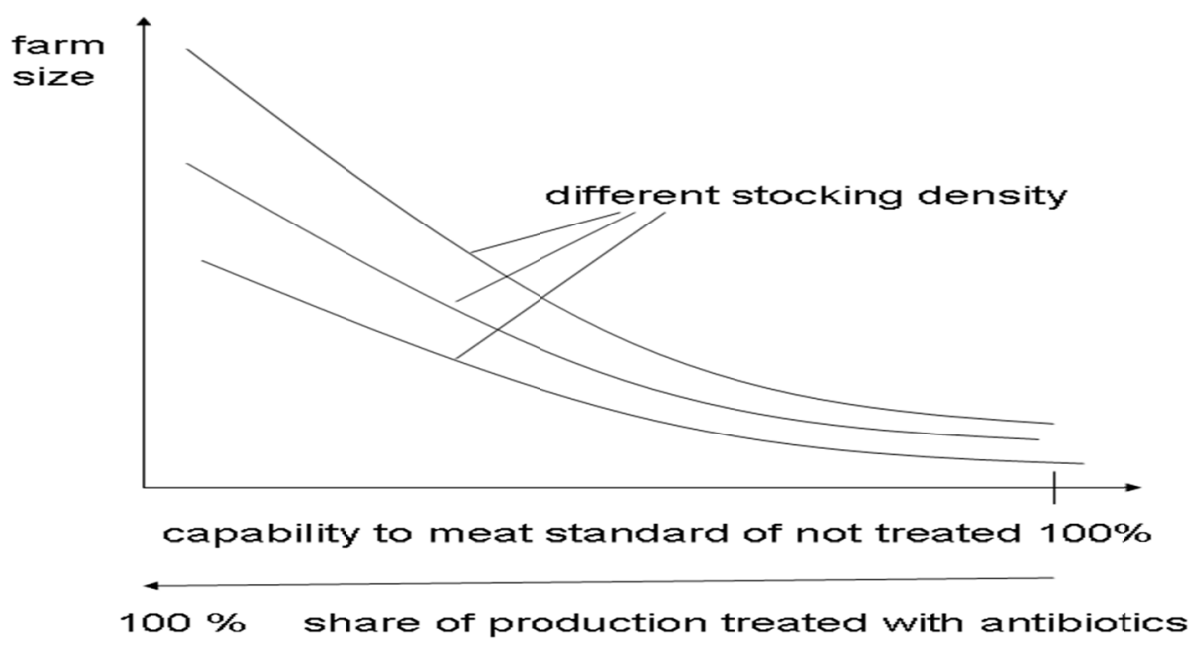

Diagram 1. Farm size and capability to meet standards for antibiotics

\subsection{Brokerage for Antibiotic-free Meat and Marketing Channels}

A necessary next step requires us to explain how to create a linkage between production modes and marketing of products. Meat products may be produced with high stocking (and antibiotics), reduced stocking, or no antibiotics (premium). We hypothesize consumers have a WTP for premium, but seek assurances of "no antibiotics", then they relate it to "low stocking" as assurance. Here, the brokerage can help. As institutional novelty brokerage can most likely fetch a price premium and assure service (low stocking density); though the broker charges a commission. He communicates a certain stocking density as antibiotics free. As generic arrangement and as mediated for exchange (here modified stocking) farmers are WTA. Promotion with consumers (finding retailer/customers) on the other side is a broker's task. We see premium meat as a market segment in which the collaboration of farmers, brokers and retailers is promoting a ban on antibiotics, controlling diseases and, as tool stocking density is fixed according to technical and veterinarian knowledge. Technical details in production are exogenous to our study. Farmers "must" reduce stocking to become entitled to a percentage of consumers' WTP to pay a premium. The broker fixes the percentage (opposite to premium for him) for efforts (promotion) which are optimized. Brokering (see below in the consecutive modelling) is figured instead of simple retailing because brokers shall look actively for premiums. Also it creates individual costs; but finally they share premiums with producers. This, for sure, is a simplification, and brokers finally use retailers to sell the meat. A broker shall be primarily active at the level of making farmers interested in premium meat and promote the meat with selected retailers. Then, at retailing we assume a competitive market and price, and premiums are paid by consumers as "price minus unit cost" for retailing. So we do not look in retailing. Perhaps the real world is more complicated since different retailer/broker interactions may result in different consumer prices and premiums; this is beyond our analysis. Also we do not go into detail how practically brokers create trust (more or less: perhaps some retailer-farmers-consortium will get highest premium, etc.); rather modelling is of priority here.

As consumers shall have choices between 3 categories of products: (i) un-controlled (rest), (ii) controlled (following negotiated terms on stocking density), and (iii) premium (quality is assured by a broker), the premium 
meat (at given stocking associated with no antibiotics) is a central element. The broker inspects attentively and is responsible for quality assurance, bears risk \& trusts vice versa. In that regard the broker "makes" the market and charges $\%$ or mark-up, i.e. if he is successful, producers receive higher prices as part of a premium. The broker charge (commission) is for services; but it is not competitive, rather negotiable. The charge is agreed as a percentage to be found jointly and an interest is created on both sides. The third party is the consumer. The "controlled" market is more complex and will be elucidated soon.

\subsubsection{Broker's Setting, Competition With Agency and Role of Free Market}

To better understand brokering and bargaining as an institutionally regulated activity of channelling purchasing power (WTP), reference scenarios need to be established. They strongly determine bargaining modes, bargaining power and success of regulations. Hence the role of brokers cannot be seen isolated. Usually modelling of political bargaining in marketing (incl. brokerage) implies a reference of no cooperation (Zusman, 1989). So what are alternatives choices, if a producer denies the services of brokerage? First, the alternative is either a "rest market of lowest quality" and price or bargaining with an agency (see below). Second, as compared to the other choices the contract must be superior. In case of farmer-broker-agency-interaction with two marketing alternatives it means "not-cooperating" with partner "A" (broker) has a reference "cooperating with partner B" (food safety agency "FSA", next chapter). As further comment: farmers like choices and this will reduce resistance to interferences giving a feeling of freedom. Bargains on conditions (choices) are necessary to reveal preference. For brokerage this means that farmers negotiate a shared price premium at a reference which is designed being the alternative. For us (later) it is working with an agency, i.e. marketing in the "controlled", negotiated channel. Vice versa, selling with an agency FSA (see again below) has brokerage as reference. Brokerage is imbedded. A semi-competitive institutional frame emerges. To look at the FSA (different mode of payment, later) from the brokerage point of view (i.e. if compensation is the bargain), such competing channel becomes relevant.

\subsubsection{Brokering Meat and Image Creation and Trust}

In practice, concerning the channel for premium meat, we need ambitious activities to create trusts and images (Lindgreen, 2003) which are apparently costly and create questions of property rights. Brokerage can be seen as simple institutional aspect of dealing with image creation of antibiotics-free-meat with regards to cost and benefit sharing arrangements. If activities lift average market price a question is who bears costs and gains? The institutional innovation is explicit cost sharing as opposed to hidden cost transmission to producers. In fact, retailer-broker-interactions must be active as campaigning, labelling, assurance, etc.; but who does what; claim rights; etc.? Here brokers can take risk. If there is the issue of: cooperation, sharing, trusting, image creation etc. (also risk taking), it can be addressed through brokerage as exemplified by Zusman (1989). Anyhow, contracting is risky for both, farmer and broker; if failures (fraud) occur, images are endangered, etc. However, in cases of risky ventures it has been shown (by theory and practice) that sharing of costs and benefits is a suitable institution (Zusman, 1989). We foresee indirect communication of farmers with retailers through brokers and trust must be assured (first to retailers) by monitoring that no antibiotics are applied. Then brokerage is market creation depending on contracting with farmers. Here we do not dig in the multiple aspects of retailing, broker, and producer interaction, rather simplify as below shown.

\subsubsection{Broker Operation}

As indicated, in the above setting, retailing through a broker shall offer marketing activities for premium meat. Institutionally a broker charges a proportional factor (commission) on surplus (premium for no antibiotics "n" vs. standard price "s", see later for implications: $v\left[\mathrm{p}^{\mathrm{n}}-\mathrm{p}^{\mathrm{s}}\right]$ and $v$ is retention of broker, producer gets $\left.(1-v)\left[\mathrm{p}^{\mathrm{n}}-\mathrm{p}^{\mathrm{s}}\right]\right)$. This rule is an institutional suggestion typical for incentive schemes (Furubotn \& Richter, 2005). Success of the suggested mechanism (hybrid scheme) relies on WTP and purchases of meat (share) at premium. At least there is risk sharing (by v) and negotiations are engrafted in sharing (see below). Also the broker bears costs of inspection. The argument is about using marketing for density reduction in an industry by brokers as offering incentives for increasing market shares vs. agency. To be clear, brokers are (in this model) not negotiating standards (here antibiotics free production); rather the job is promotion and market creation for premium meat of lowest density (no antibiotics).

\subsection{Agency of Controlling Stocking and Compensation for Antibiotic Control}

Alternatively to brokers meat producers can (shall) contract with an agency which has money to promote negotiated changes in stocking density. The agency negotiates on flexible standards to get participation which is voluntary; here food prices are given and compensation is negotiated. Our Food Safety Agency, we call it "FSA", is yet to be initiated (though in Germany, for instance, "QS" plays partly the job: QS, 2013a). It is considered 
semi-autonomous, as parastatal; i.e. it shall represent the public goals, and it anticipates public concern (public WTP for reduced antibiotics). Especially, we have to clarify how it will be equipped with money. We see a possibility to get money from health care based on public WTP for antibiotic control (not private WTP for premium meat as with brokers; rather a secondary source of money as WTP for health). How does FSA function? For the agency we assume that it "buys in technology" giving producer compensation at lowest costs (negotiates on stocking density and compensates farmers: WTA). Supposedly, in economic terms, there is a WTP for a probable reduction of health risk by changing practices (yet citizens', not consumer' money for lower stocking). The assumption is: a positive net effect in a cost-benefit (CBA) from stocking density reduction. The agency requests a budget from public health on basis of achievements and compensates farmers for cost increases due to less economies of scale (lower stocking density). We assume that property rights are with farmers. In other words, FSA shall "convince the industry" (actually as majority) that using fewer antibiotics (reduce stocking) will be of benefit to them (indirectly; this will result in overall reduced antibiotics as negotiation parameter). Note, one can go even further and talk about an index of various farm practises, but that needs new agreements (Agrarheute, 2014) and it raises issues whether in the end it will block agreements because of no clear commitments. Bargaining can be constructed as follows.

\subsubsection{Bargaining Outline for the Agency}

For operational feasibility a special outline of bargaining (as part of the novel institutional set-up) is suggested (i.e. created: see below). We try to reduce complexity and work with stocking density as a simple measure (eventually extended). In fact, our suggestion offers a normative outline for a quality assurance (FSA), yet to be established. It has to be constructed because it does not exist in most countries. However, offering an interest function to be pursued and bargaining (referring to economic theory) means to support real issues. Bargaining usually works by outlining bargaining parameters that are agreed upon in a mode of real exchange (Zusman (1989). For comparison and transfer of this concept: usually an agency, as a unit working with fixed price, charges a fixed rate for services (cost plus mark-up). Financial surpluses come from operating a service which is cost compensated. In our case we introduce bargaining on stocking density in exchange for payments and assume that FSA is a bureaucracy with surplus.

To spell out the underlying assumptions on establishing FSA: in a first version, i.e. in a deterministic approach by which bargaining can be conceptualized as an incentive and cap-and-trade system, compensation is a negotiated payment. In this system the control of antibiotics (stocking density) is the task to be accomplished through a self-regulatory element in industry (payment). A second version would be a probability-wise approach including "illicit" behaviour and fining; i.e. if, in cases, farmers fail to comply with stocking they are fined generating cash. Then revenues are different. Both, financial returns from fining and money by the agency/government for health can be used to pay farmers who are WTA reductions in stocking and comply with regulations. In the first case money solely comes from public WTP for health. In the second case there is a chance for an own budget where money comes also from farmers, (fined), but costs for inspection are to be included. We take the first version because it is much easier to model. Further note that bargains are individual ones, which opens up flexibility.

\subsubsection{Agency Behaviour and References}

As said in the introduction, our design of FSA will follow basically the concept of Zusman (1989). This concept is moreover based on reference points for creating cooperation as well as on specifying interest functions of parties (i.e. here the agency FSA and farmer, see below in the bargain outline). Starting with the first aspect, it is important to note that our references in dealing and bargaining with the FSA are either the broker (the no-antibiotics option) or not participating (zero change option). As said the project is voluntary. Then, interests of producers, as variation in regulations (practices, incl. bans or change in stocking), can be specified as follows: choices are determined by profits, i.e. on (i) sales at "free" rest markets, (ii) program or (iii) premium market. However, producers must be encouraged to cooperate with the FSA. Working with FSA at individual stocking density reductions and with brokers, it must be seen as income change. Essentially, FSA should serve those farmers with modest wishes for reduction, supplementing income. The FSA has to be imbedded in mutual (multiple) bargains offering farmers gradual choices. From a FSA viewpoint, bargaining of endogenous regulations is revenue maximizing. Hitherto we will model FSA as bureaucracy in accordance with Niskanen (1971). Since we may consider it a parastatal and not company, this modifies the interest function (see below). In such bureaucracy, it has to be assured that interest is created and FSA is not of "natural" interest. Interest will be given as striving for budget sizes. 


\section{Mathematical Outline}

In fact, there are three marketing channels which interact, we have to look behaviour, and we have to look at costs. Producers have choices with conflicting interests: they deliver meat simultaneously (or at corner solution) to (i) a rest market at low price (or export to a world market without regulation), (ii) domestic market with competitive prices plus compensation (at negotiated stocking density) or (iii) "premium" market with high price for meat. Producers alternatively contract with brokers on surcharge in case of premium prices (no-antibiotics and low stocking) or on (endogenous) stocking density for compensation. A comparison for this is provided in Zusman (1989). Calculating ad(dis)vantages from modification of marketing choices becomes optional and broker participation is premium, though responsibility for product (meat) image is joint (active). Brokerage has to be seen in institutional mixture with FSA.

In this section we will explain how to model connectivity between the interest functions of the industry (as to be derived) and contracting variables (as achievements), i.e. in terms of: (i) stocking density (antibiotics use), (ii) premium sharing (channelling WTP from consumers to farmers, incl. commission: privately) and (iii) compensations (using health care money: publicly). The mathematical outline serves to settle the conflict; antibiotics vs. stocking density by compensation payments and negotiations based on a mathematical concept of bargaining developed by Zusman (1989). Such outline further enables us to do a quantitative analysis on power in games (as revelation mechanism). Power is needed to establish the bargain (below).

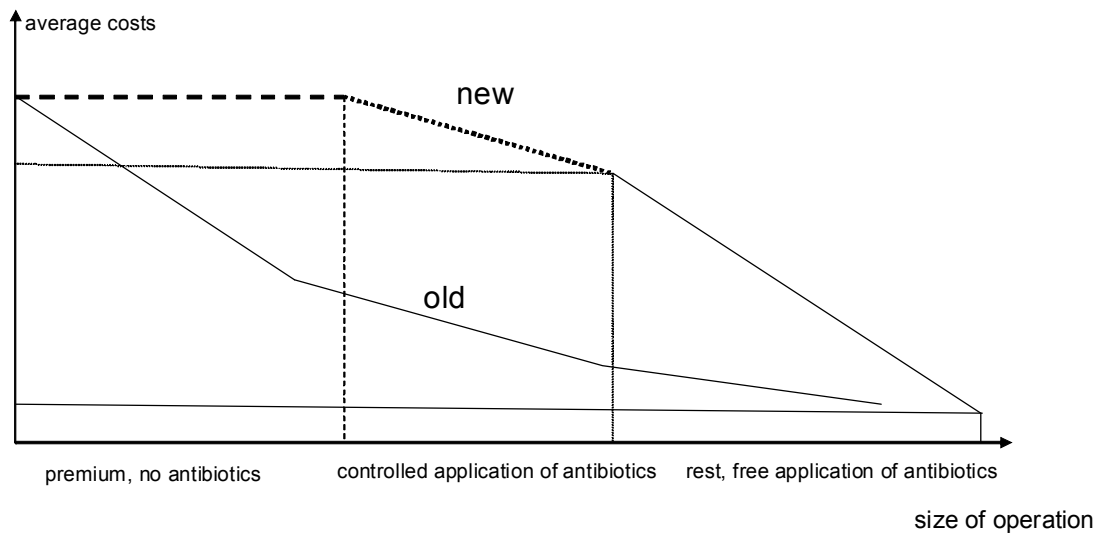

Diagram 2. Average costs

To start: produces and costs are segmented into three parts (according to economies of scale see Diagram 2). We assume that the industry's operation is separable in three sections. For instance, the first part (meat produced without antibiotics at lowest stocking density) has highest costs according to fixed regulations for animal health and welfare. (Technologies are actually considered exogenous to this paper, though they adjust). Here, in part (i) no economies of scale form changing stocking can be achieved. The part (ii) contains negotiated practices as explained above which allows slight change in scale, and the last part (iii) is free of any control and ends up at maximum stocking given by regulations as legal practices (minimum). In this section we have the strongest decline of economies of scale. We distinguish further the old and new patterns of economies of scale after and before using new institutional set-ups.

In each part or market segment, products with different consumer preferences and different economies of scale prevail. In section (i) production is based on high costs of caring for hygiene, good forage, air conditioning, etc. and perhaps it is out-door or organic farming (but this aspect does not matter here). Looking at mathematical expressions a continuous costs function is deployed; in reality, it is vital how animals are raised. In segment (ii) there is, as a result of compensation, a moderated decline in economies of scale (as compared to a reference of a previous medium scale farming incl. without compensation even thresholds change). In segment (iii), still a strong cost decline can be reached because stocking density regulations are standard only and antibiotic application still allows densities of animals beyond controlled.

Producers (or a single farm, if we allow multipurpose operation) decide on production categories and deliveries to markets according to options along segments. Two cases might be distinguished: in case one a producer delivers only to one segments, for example premium meat, while in case two a continuum is assumed. Case one is difficult to be addressed mathematically. We work with a continuum. In that case the producer can serve all 
segments and decisions are internal. Given knowledge and references for economies of scale in segments, there are two modes of sector modelling: (a) it is a decision to accommodate all segments being endogenous or (b) groups of farmers decide for modes of farming (i.e. producers are going individually for "no: c", "controlled: c", or "rest: $r$ ".) To simplify (as abstraction) in "premium" stocking density is not disputable and we restrict decisions to market channel volumes. Then, the average application rate of antibiotics in relationship to average density " $\mathrm{d}$ " " is determined endogenously by average segment densities and sizes of segments (market shares).

$$
d^{a}=\varsigma_{n} d_{n}+\varsigma_{c} d_{c}+\left[1-\varsigma_{n}-\varsigma_{c}\right] d_{r}
$$

where: d: stocking density of a: average industry , n: no antibiotics (broker), c: controlled (agency), r: rest, $\varsigma_{: i}$ : share of production for $\mathrm{r}$ : rest, c: compensation and n: no-antibiotics

The stocking densities "d" (for c and r) will soon be determined (endogenously) and we will relate the average densities to expected antibiotics involved in production. This is important for the creation of WTP. Note, in the first segment, $\mathrm{d}^{\mathrm{n}}$ is fix, no antibiotics are applied; as said this is correlated with highest cost in animal rearing (though these higher unit costs are enabled by premiums). In the second segment, stocking density is a matter of negotiation (as bound to compensation) and in the third segment farmers freely decide. To decide freely means that no real standard prevails on stocking. The government's role is the following: it has to decide about allowed antibiotics as standard (in segment " $r$ " farmers declare being member r). The explanatory equation contains average costs as function of shares of economies of scale costs:

$$
c^{a}=\varsigma_{n} c_{n}+\varsigma_{c} c_{c}+\left[1-\varsigma_{n}-\varsigma_{c}\right] c_{r}
$$

where: c: average costs of a: average, $n$ : no antibiotics (brokerage), c controlled (agency), r:

rest, $\varsigma$ : share of production for ...

This specification parallels Equation (1). From the two Equations (1) and (2) we seek to determine the average costs. We assume the cost function for all produces has a quadratic expression as usually used in supply analysis (i.e. costs increase by produce and this is over-proportional: concave); but we blend it with economies of scale. Equation (3) states that coefficients of curvature are dependent on stocking density. Economies of scale are given as follows:

$$
C^{a}=\gamma_{10}^{a} q_{t}+0.5\left[\gamma_{10}^{a}+\gamma_{11}^{a}\right] q_{t}^{2} \text { and } \gamma_{11}^{a}=\gamma_{110}^{a}+\gamma_{111}^{a}\left[1-r_{t} / q_{t}\right]
$$

where additionally: q: production of $\mathrm{t}$ : total produce, r: room for animal (space).

$$
C^{a}=\gamma_{10}^{a} q_{t}+0.5\left[\left[\gamma_{10}^{a}+\gamma_{110}^{a}\right] q_{t}^{2}+\gamma_{111}^{a} r_{t} q_{t}\right]
$$

The joint function, given in Equation 4, contains the technology parameters, economies of scale as animal density and production volume as determining variables. This cost function is based on parameter " $r$ " depicting economies of scale in technologies as well as depends on marginal and average costs being subject to decisions on scales. For unit (average) costs it is:

$$
c^{a}=\gamma_{10}^{a}+0.5\left[\left[\gamma_{10}^{a}+\gamma_{110}^{a}\right] q_{t}+\gamma_{111}^{a} r_{t}\right]
$$

Type (5) determination of average (unit) costs, in combination with Equation (2) and both equated, gives a reliance of meat industry as stated, dependent on scale technology as equilibrium:

$$
\gamma_{10}^{a}+0.5\left[\left[\gamma_{10}^{a}+\gamma_{110}^{a}\right] q_{t}+\gamma_{111}^{a} r_{t}\right]=\varsigma_{n}\left[c_{n}^{c}-c_{r}\right] \varsigma_{n}+\varsigma_{c}\left[c_{c}-c_{r}\right] \varsigma_{c}+1 c_{r}
$$

Further, if (as well since we have constant average costs) we have $c_{n}^{c} / d_{c}^{c}$, we get:

$$
d_{n}^{c} \gamma_{10}^{a}+0.5 d_{n}^{c}\left[\left[\gamma_{10}^{a}+\gamma_{110}^{a}\right] q_{t}+d_{n}^{c} \gamma_{111_{t}}^{a}-d_{n}^{c}\left[c_{c}-c_{r}\right] \varsigma_{c}+d_{n}^{c} c_{r}=\left[c_{n}^{c}-c_{r}\right]\left[\left[d_{c}-d_{r}\right] \varsigma_{c}+d_{r}\right]-d^{a}\right]
$$

In principle, Equation (7) offers a delineation of average stocking density based on market shares; coefficients 
are settled. We need this later for negotiation modelling and WTP.

$$
d^{a}=\gamma_{10}^{*}+\gamma_{11}^{*} \varsigma_{c}+\gamma_{12}^{*} q_{t}+\gamma_{13}^{*}+\gamma_{14}^{*}\left\{c_{c}-c_{t}\right\}+\gamma_{15}^{*} c_{r}+\gamma_{16}^{*} d_{c}+\gamma_{17}^{*} d_{r}
$$

For interpretation of Equation (7'): looking at average costs and stocking density simultaneously and linking those to antibiotics use (where density is a measure of probable use intensity), a linear constraint prevails for representative producers. This is important for bargaining. In modelling, Equation (7') enables us (i) to reduce the number of variables in negotiations from the side of producers, (ii) limits choices in regards to markets, and (iii) enables us to find an analytical solution. For Equation (7') all coefficients should be easily retrievable (by econometrics), i.e. from market settings in which segments are optimized for local and total economies of scale, i.e. where " $d_{r}$ and $c_{r}$ " are maximum and technology given. The market shares are yet free of choice and indicate sizes of operation in terms of references. In particular, the corresponding stocking density for residual " $\mathrm{r}$ " can be (is) set by government as maximum which is the immediate choice of producers in this segment. Stocking density in the no-antibiotics case "n" (as fixed coefficients) is also given technology-wise. Recursively we only have to determine stocking density in the controlled segment "c" as $d_{c}$ by bargaining, i.e. endogenously (subject to the negotiation with the agency). In terms of institutions FSA fixes it.

Then market share " $\zeta_{c}$ " of controlled production will be also determined by the agency based on its cost-benefit analysis and available budget (compensation money, see below), i.e. it is in the capability of FSA to actually control the industry in size including transaction costs and its capability counts for success based on achievements, recursively, by budgets given to it. The central choice variable (i.e, variable in the negotiation) is stocking density $d_{c}$ of animal population in the controlled segment and this makes calculations for achievable average cost $\mathrm{c}_{\mathrm{c}}$, in the segment and total industry important. This last aspect is chief for compensation calculation and the trigger to change in the system. Internally, the industry costs $\mathrm{c}_{\mathrm{c}}$ becomes negotiable, been grounded in compensation. Compensation is envisaged as gearing the system and part of any negotiations with producers. But, since not a classical market prevails also "prices" are indirectly negotiated, i.e. overcompensated as a likely effect based on power. Power in negotiations depend on market volume $\mathrm{q}_{\mathrm{r}}$ (expressed as $\zeta_{\mathrm{r}}$ ) in other segments. All production volumes and given shares (n, c, r) can be linked to sales with brokers. Because of that we start with brokerage. Now finally $\mathrm{d}^{\mathrm{a}}$ is the policy variable (government) since it expresses antibiotics use.

\section{Objective Functions of Participants (Producer, Retailer and Safety Agency)}

As segmentation creates markets (options) and shares (negotiation) we have to establish objective functions. Objective functions are to be specified for (i) producers, (ii) FSA, and (iii) brokers (working with retailers. In our bargaining, i.e. as retrievable game, consumers, retailers and government are passive. Also it is not a game in an analytic fashion of Myerson (1991); rather it looks for recovering parameters from revealed negotiations by reconstruction of objective function and optimization: Zusman, 1989, the game is indirect). A priority is given to interaction and negotiations. At the same time certain variables are to be put in a position to be parameters for negotiation. Parameters are to be forged as mutually conflicting and are expressed in modes enabling calculations of instant costs and benefits. It means, at times, producers receive offers from brokers and the FSA, which are to be informed on acceptance.

\subsection{Objective Function of the Producer}

We start with a producer who makes choices on marketing (channels), delivers meats designed for segments " $\mathrm{n}$, c, r", i.e. priority choices in marketing on basis of cost-benefit calculations, as well as negotiated parameters (compensation for controlled produce and sharing premiums).

$$
\Pi=R^{n}-C^{n}+R^{c}-C^{c}+R^{r}-C^{r}
$$

where additionally R: revenue: n: no antibiotics (brokerage), c controlled (agency), r: rest

Again note as assumed in segment " $n$ ", here no economies of scale do prevail towards stocking density and decision is on market shares. In segment "c" economies of scale are moderated through limitations (reduction through bargained control for lower stocking density which is reducing antibiotics use) which increase costs and in segment " $r$ " there is no control.

With respect to the idea of having primarily a bargain on stocking density in segment "c" this has to be modelled negotiating space (density) per animal. For simplicity, industry decisions are taken in combination with each other. This means we assume that each producer produces can serve potentially all market segments. Then we can write the objective as function (8): 


$$
\Pi=R^{n}-c^{n} q^{n}+R^{c}-c^{c} q^{c}+R^{r}-c^{r} q^{r}
$$

Inserting of the above cost specification (Equation 3) gives:

$$
\Pi=R^{n}-c^{n} q^{n}+R^{c}-\left[0.5\left[\left[\gamma_{10}^{c}+\gamma_{110}^{c}\right]+\gamma_{111}^{c} 1 / r_{0}^{c}\left[1-r^{c} / q^{c}\right]\right]\right]\left[q^{c}\right]^{2}+R^{r}-c^{r} q^{r}
$$

Consecutively, Equation ( $\left.8^{\prime}\right)$ then delivers:

$$
\Pi=R^{n}-c^{n} q^{n}+R^{c}-0.5\left[\left[\gamma_{10}^{c}+\gamma_{110}^{c}\right]+\gamma_{111}^{c}\left[q^{c} / r^{c}\right]\right] q^{c}+R^{r}-c^{r} q^{r}
$$

And the objective can be further explained in shares of the market segments

$$
\Pi=\left[p^{n}+p^{c}+p^{r}-\left[c^{n} \varsigma^{n}-0.5\left[\left[\gamma_{10}^{c}+\gamma_{110}^{c}\right]+\gamma_{111}^{c}\left[q^{c} / r^{c}\right]\right] \varsigma^{c}-c^{r}\left[1-\varsigma^{n}-\varsigma^{c}\right]\right] q^{t}\right.
$$

Objective function (10) reduces the no. of options for negotiation towards: market shares of meat in the premium $\zeta_{\mathrm{c}}$, stocking density $\mathrm{r}_{\mathrm{c}}$, and share in premium increase $1-v_{\mathrm{i}}$ (for individual producers knowing $v_{\mathrm{i}}$ is commission). Stocking density is linked to compensation. Finally, some remarks on residual $\mathrm{q}_{\mathrm{r}}$ and total production $\mathrm{q}_{\mathrm{t}}$ : they are implicitly integrated as free optimization and as outside to the negotiation. Since the intention is to model bargaining and not decisions in total, we consider production decision secondary to industry and consider it exogenous. This not applies to premium's market share where quantities are determined by consumers and government will. To complete the analysis, the task of a broker is to negotiate that share, i.e. yet it has to be integrated. This implies that price $\mathrm{p}_{\mathrm{n}}$ (as been observed by producers) is variable (in fact a market analysis is needed); it is part of negotiation (optimization in bargaining). Because price increases are shared (see above), finally, the objective can be stated as:

$$
\Pi_{i}=\left[\left(p^{c}+\left[p_{s}^{n}-p^{c}\right]\left[1-v_{i}\right]-c^{n, r}\right) \varsigma^{n}+\left(p^{c}-c_{10}^{c}+\gamma_{11}^{c} d^{c}\right) \varsigma^{c}-p^{r, n e t}\right] q^{t}
$$

In other words: variables in negotiations are (i) market share of meat $\varsigma^{\mathrm{n}}$ (as $1-\varsigma^{\mathrm{c}}-\varsigma^{\mathrm{r}}$ : sold with no-antibiotics), (ii) stocking density (now as $\mathrm{d}^{\mathrm{c}}$, derive from $\mathrm{r}^{\mathrm{c}}$ and $\mathrm{c}^{\mathrm{c}}$ linked to $\mathrm{d}^{\mathrm{c}}$ ) and (iii) share of controlled produce $\varsigma^{\mathrm{c}}$ (determined by FSA: where we see interaction and sequential optimization). Likewise (iv) there is scope for improved revenue (1-v) that is dependent on brokers' activities in marketing/promotion. The rest of production (share in production capacity) is implicit and the prices for the rest and compensated market are unchanged (export) prices.

\subsection{Introductory Remark on the Role of Marketing Units for Reduction}

Remember we spoke of creating marketing channels and promoting negotiations as a tool to reduce stocking density and antibiotics, i.e. going for "less antibiotics" (synonym for having less production of "rest meat") at industry level. Now issues in "designing bargains" emerge. First, a question is: how to include public concern for health? Second, channel 3 (rest) which produces uncontrolled food is the problem. It indirectly matters and the aim is to reduce its shares. So how can a broker provide incentives and how is this mathematically retrievable? $\mathrm{He}$ is a master player in terms of premium (given in Equation 12 in vein of Zusman, 1989); i.e. channelling better meat prices to producers. His interest is gaining commissions. He ensures (i) no antibiotics are used, (ii) promotes sales and (iii) offers farmers premiums. The intermediary FSA instead is controlling (stocking, not markets); FSA is needed to calibrate alternatives at lower level commitments and to offer alternatives in negotiations by giving fixed payments.

\subsection{Broker}

Additionally to revenues (i), which are determined by the shares which can be achieved in premium meat, the broker's objective function (working through retailing) shall comprise (ii) costs of promotion, inspection, handling, etc. and market share (iii) determine volumes:

$$
\left.B=\left(p_{s}^{n}-p_{c}\right) v_{i}\left[\sum_{i} \varsigma_{i}^{n} q_{i}^{t}\right)\right]-\zeta_{b} s_{b}-C_{b}\left(\sum_{i} \varsigma_{i}^{n} q_{i}^{t}\right) \varsigma_{n}^{n}
$$

where additionally: $v$ : sharing of price increases

$\mathrm{s}$ : search and promotion (costs)

$\mathrm{C}_{\mathrm{b}}$ : cost of control by the broker for the purpose of quality assurance (no antibiotics) 
To a large extent, the objective function (12) fits with that of Zusman (1989) for a broker. An amendment is control costs of antibiotics (on stocking density and animal health as transaction cost). In general terms the broker takes care of inspection and internalizes transaction costs. We assume brokers receive a licence by government through label approval. Then the average application can be accumulated and additional costs are included based on " $\mathrm{d}$ "):

$$
\left.B=\left(p_{s}^{n}-p_{c}\right) v_{i}\left[\sum_{i} \varsigma_{i}^{n} q_{i}^{t}\right)\right]-w_{g}^{n} d^{a}-\zeta_{b} s_{b}-C_{b}\left(\sum_{i} \varsigma_{i}^{n} q_{i}^{t}\right) \varsigma_{n}^{n}
$$

To supplement the approach the premium price is a function of "sensitizing markets": $p_{s}^{n}=f_{S}\left(s_{b}\right)$ (promotion and guaranteeing). Such sensitizing is similar to Zusman's (1989) search task. Yet, negotiations with farmers are on market shares $\varsigma^{\mathrm{n}}$ which shall increase. The issue involved is solidifying consumers' trust in no-antibiotics meat or reducing average use.

\subsection{Food Safety (Assurance) Agency}

The objective function of the FSA is more complicated to establish than the brokers' one. "Establishing" refers to behavioural arguments which are not "natural" in this case. FSA shall work on behalf of a government, but may as well be constituted formally as non-profit organization (eventually association: as legal entity) and a question is how it "behaves". This means that meat processors and traders can join an association which is professionally managed by a board along interest. The board has a budget. Budgets improve status and set rules for trading.

So what modelling option do we have for FSA? FSA can be considered as a bureaucracy licensed by government and being supported by industry as long as interests are met. We assume FSA receives a budget derived from WTP for reducing antibiotics (health care) based on technology (stocking density). I.e. there is a causality chain from health [less antibiotics], along performance [technologies] to characteristics [stocking density]. FSA maximizes its budget given the condition of balancing costs and benefits (Niskannen, 1971: see in Diagram 3). FSA makes no profits; instead revenues shall be equated with costs. Revenues are modelled as incoming WTP for reduction of antibiotics specified as dependent on stocking density. To exemplify: Diagram 3 shows a downward sloped marginal WTP, i.e. offers are optimized (negotiable/monitored). The issue behind in modelling is how to obtain a mathematical outline linking budget maximization and compensation to stocking density. Note, it is not a social optimum; but interests shall be created. We look for improvement and action instead of blocking.

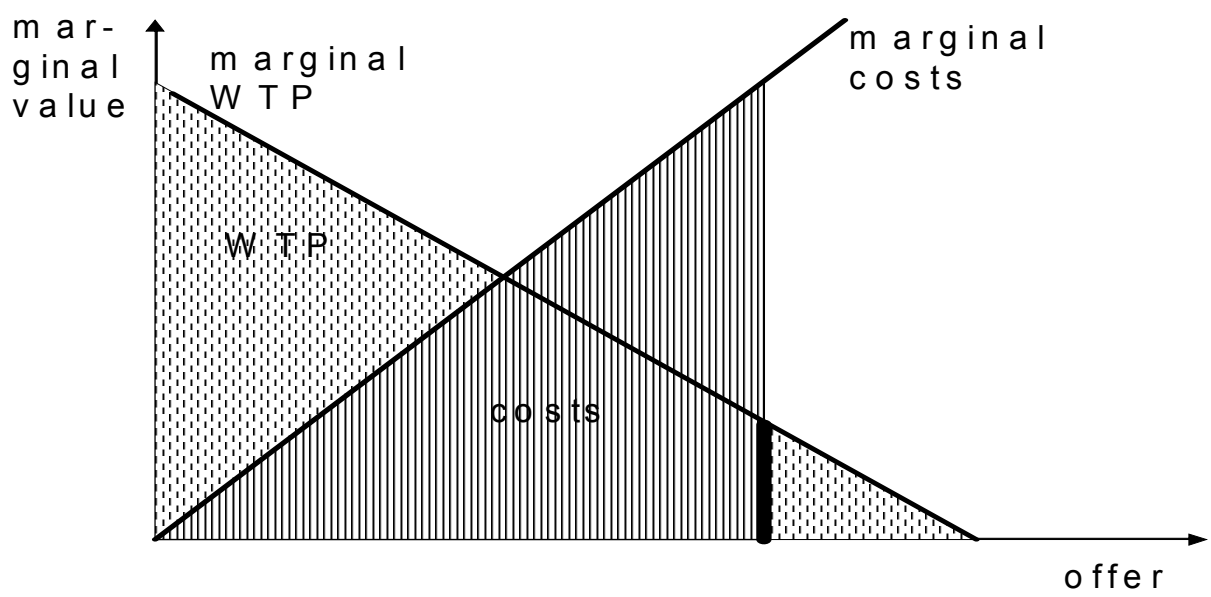

Diagram 3. Bureaucracy behaviour according to niskannen

In order to make things operational: WTP can be enumerated within two scenarios: (a) where stocking density reduction is feasible based on quantified measures (compensated against current state of high antibiotics and its costs; i.e. it changes by improved farming practices complying with administrative control), or (b) a scenario of WTP for straight low future antibiotics use which would be per unit and achieved by transparent accounts of antibiotics at farms. For both, marginal WTP in principle could be formulated and this gives a "welfare" function, 
i.e. if marginal payment is stated. We take (a) assuming lower transaction cost involvement. We here base WTP on stocking density as reduction (from current average level of industry, giving government checks, easy measuring, approval, etc.) for a release of the budget:

$$
W T P=-\theta_{10}^{w}\left[\sum d_{i}^{a}-\sum d_{i}^{r}\right]+0.5 \theta_{11}^{w}\left[\sum d_{i}^{a}-\sum d_{i}^{r}\right]^{2}
$$

Revenue (from public WTP) and cost (compensation as WTA plus transaction costs: personal, monitoring costs, etc.) can be modelled for FSA by the thought as equating costs and revenue. If stocking density reduction shall be $\mathrm{D}=\Sigma \mathrm{d}_{\mathrm{i}}$, it gives money along a Niskanen (1971) concept (as in bureaucracies) expenditures. Cash receipts equal cost (now excl. own costs of operation, labour costs, laboratories, etc. being proportional to units) if no profits prevail. Whence the budget is maximized; cost equal revenue is a constraint. In actuality costs incurred may be more complicated to measure. Let us stick to a simple mathematical outline, though we are aware there are further costs (information, special control costs, new laboratory costs, etc., not only compensations and expenditures as in accounting). Nevertheless we summarize them all into transaction costs of FSA: $\mathrm{C}_{\mathrm{A}}=$ $\mathrm{C}_{\mathrm{A}}\left(\mathrm{D}^{\mathrm{a}}, \mathrm{S}\right)$. Also to make things less complicated for modelling we assume that costs are linear, i.e. revenues and costs are a function of $\mathrm{D}$ and $\mathrm{w}$, where $\mathrm{w}$ is unit cost: this allows us to split services of FSA (measured as reduction of density $\left[\mathrm{D}-\mathrm{D}_{\mathrm{r}}\right]$ ) and compensation; all multiplied with $\mathrm{w}$ (unit costs), i.e.: D.w. For expression see Equation (15):

$$
R-E=S_{0} D_{b 0}+\left[S_{0}-S\right] D_{b 0}+S\left[D_{b}-D_{b 0}\right]-c_{c}^{a} D_{i}
$$

where additionally: D: average density in the industry. $\mathrm{S}$ or $\mathrm{s}_{\mathrm{a}}$ : subsidy equivalent for unit costs which can be expressed as average subsidy.

Establishing the objective function as integral over marginal revenue (WTP), giving the constraint as well as maximizing, we apply a Lagrange expression (16, derived from reduction from WTP, as measure for D). This is firstly done for the agency at the summarized level $\mathrm{D}=\Sigma \mathrm{d}_{\mathrm{i}}$ :

$$
A=-\theta_{10}^{w}\left[D_{b}^{a}-D_{b}^{r}\right]+0.5 \theta_{11}^{w}\left[D_{b}^{a}-D_{b}^{r}\right]^{2}+\lambda\left[s_{a, 0} D_{b 0}^{r}+\left[s_{a, 0}-s_{a}\right] D_{b 0}^{r}+s_{a}\left[D_{b}^{a}-D_{b 0}^{r}\right]-c_{c}^{a} D_{b}^{a}\right]
$$

where (16) is the FSA's objective. For optimization of D and shadow price we get:

$$
\begin{gathered}
\partial A / \partial D_{b}^{a}-\theta_{10}^{w}+\theta_{11}^{w}\left[D_{b}^{a}-D_{b}^{r}\right]+\lambda\left[s_{a}-c_{c}^{a}\right]=0 \\
\partial A / \partial \lambda=\left[s_{a, 0} D_{b 0}^{r}+0.5\left[s_{a, 0}-s_{a}\right] D_{b 0}^{r}+s_{a, 0}\left[D_{b}^{a}-D_{b 0}^{r}\right]-c_{c}^{a} D_{b}^{a}\right]=0
\end{gathered}
$$

and the shadow price is a function of a reduced form

$$
\lambda=\theta_{10}^{*}+\theta_{11}^{*} c_{c}+\theta_{12}^{*} s_{a, 0}+\theta_{13}^{*} s_{a}+\theta_{14}^{*} D_{b 0}^{r}+\theta_{15}^{*} D_{b 1}^{r}
$$

Hereby $\lambda$ and $D$ are simultaneously optimized (solved). Inserting them in the initial objective function provides a residual objective function of FSA which is ready for bargaining with individual producers' reduction of density " $\Delta \mathrm{d}_{\mathrm{i}}$ " as dependent on parameters set in bargaining.

Optimizing Equations (16) for FSA, i.e. dealing with multiple producers, was yet at industry level; but also it can serve as reference for individual bargaining. Industry-wide optimization tells the FSA (as reference) what can be achieved in terms of budget accumulation based on getting WTP for average reduction from the government. Hereby, FSA is an agent on behalf of the government and to a certain extent government is a principal, but it has delegated matters to FSA. We must further admit Equations (16a to c) do not provide the "social optimum". Nevertheless, because our societal "approach" is based on interests, it is "material" and pecuniary. Note if trading with individuals it is below possible achievements, some WTP is lost.

For (re-)construction of the FSA's interest function (i.e. bargaining with producers) on stocking density and also compensation of average costs, it is necessary to insert the average density (in reduced form as above) into the objective A (see 17):

$$
A=-\theta_{10}^{*}\left[D_{b}^{a}-D_{b}^{r}\right]+0.5 \theta_{11}^{*}\left[D_{b}^{a}-D_{b}^{r}\right]^{2}
$$

Then, for the sake of later depiction of individual bargains (given generalized interdependencies between 
average costs, stocking reduction and bargaining variables (such as individual average costs $\mathrm{c}_{\mathrm{ci}}$, reduction request $\mathrm{d}_{\mathrm{ci}}$ and market share $\zeta_{\mathrm{ci}}$ ), the changes on density have to be broken down to individual contributions. Adding them and using market-wide relationships

$$
D_{b}^{a}=\gamma_{14}^{*} \sum_{i}\left\{c_{c i}-c_{t}\right\}+\gamma_{16}^{*} \sum_{i} d_{c i}+\gamma_{10}^{*}+\gamma_{11}^{*} \varsigma_{c i}+\gamma_{12}^{*} Q_{t}+\gamma_{13}^{*}+\gamma_{15}^{*} c_{r}+\gamma_{17}^{*} d_{r}
$$

we can now determine the objective function of FSA for bargaining at individual level. In respect of interactions with average costs, we get Equation (18). It brings in individual compensation for farmers as directed subsidy for producers in eye of society:

$$
\begin{aligned}
A= & \theta_{10}^{*}\left[\gamma_{14}^{*} \sum_{i}\left\{c_{c i}-c_{t}-s_{c i}\right\}+\gamma_{16}^{*} \sum_{i} d_{c i}+\gamma_{10}^{*}+\gamma_{11}^{*} \varsigma_{c i}+\gamma_{1 x}^{*} x_{i}-D_{b}^{r}\right]+ \\
& 0.5 \theta_{11}^{*}\left[\left[\gamma_{14}^{*} \sum_{i}\left\{c_{c i}-s_{c i}-c_{t}\right\}+\gamma_{16}^{*} \sum_{i} d_{c i}+\gamma_{10}^{*}+\gamma_{11}^{*} \varsigma_{c i}+\gamma_{1 x}^{*} x_{i}-D_{b}^{r}\right]^{2}\right.
\end{aligned}
$$

Yet Equation (18) is a function of (i) average costs $\mathrm{c}_{\mathrm{c} i}$, (where the spread of average costs shall be compensated by $\mathrm{s}_{\mathrm{c}}$, which is the subsidy paid for density reduction $\Delta \mathrm{d}_{\mathrm{i}}$ ), (ii) individual reduction request $\Delta \mathrm{d}_{\mathrm{i}}$ (associated with increase of costs), and (iii) market share $\zeta_{\text {ci. }}$. All these parameters can be determined in negotiations with individual producers on basis of delineating the marketing alternatives and jointly negotiating and fixing compensation in competition.

In fact, at individual level, the FSA shall address $\mathrm{c}_{\mathrm{ci}}$ as dependent on $\Delta \mathrm{d}_{\mathrm{i}}$ and look at changes fitting producers: $\mathrm{c}_{\mathrm{ci}}$ $-\mathrm{c}_{\mathrm{ci}, 0}=\gamma_{\mathrm{ci}}\left[\mathrm{d}_{\mathrm{ci}}-\mathrm{d}_{\mathrm{ci}, 0}\right]$. There might be overcompensation and market shares are affected; but having additional information on how $\mathrm{s}_{\mathrm{ci}}$ stimulates $\zeta_{\mathrm{ci}}\left(\right.$ at given $\left.\left[\zeta_{\mathrm{ci}} \zeta_{\mathrm{ci} .0}\right]=\gamma_{\mathrm{ci}} \mathrm{s}_{\mathrm{ci}}\right)$ this helps finding solutions. Here we have to see interfaces with brokers. The broker's $\zeta_{\mathrm{bi}}$ and residual market share $\zeta_{\mathrm{ir}}$ add to $\left(1-\zeta_{\mathrm{ci}}\right)$. It means $\zeta_{\mathrm{bi}}+\zeta_{\mathrm{r}}=1-\zeta_{\mathrm{ci}}$. Producers negotiate with partners indirectly and a quasi-competitive situation for service of stocking reduction is found.

\section{Bargaining}

Having clarified the interest functions and modes of conduct (i.e. how interests can be expressed for bargaining) procedures as dependent on parameter, features and routines of bargaining have to be specified. This can be done and exemplified as well as modelled as system optimization. In fact, it has to be shown how bargaining helps in achieving public goals (reduction of antibiotics and a cost-benefits), and we have to be put goals into an operational perspective (i.e. within a theory of political economy). We hereby refer to the theory of Zusman (1976 and 1989) which is based on cooperative games (Harsanyi, 1993). This theory links individual interest functions to a weighted "interests" of society. In his example on referenced bargain Zusman has shown how to put marketing decisions and negotiation on contracts into a mathematical framework. Though real simulations are needed for application, here we only can sketch them as illustration. In the paper we have worked out interest functions which fit the frame of Zusman (1989). So the coining of interest functions is ready for application. Any actor (broker, agency and producer) is modelled as having opposed interests on mutually exclusive parameters given choices and references for parameters, i.e. of competing options. In regards to producer/broker and FSA/producer it links objectives as references.

To sketch the idea as has been outlined by Zusman (1989), one can convey bargaining as a modelling (interactive optimization) with weights. Bargaining offers contract parameters in terms of measureable agreements and it shows how one can retrieve power coefficients from observable bargains (cooperation vs. non-cooperation, which is given in Diagram 4; the weights are the power coefficients). Technically bargaining is modelled as optimization and deriving a power function is done simultaneously. The aim of the power analysis is to obtain both, contract parameters and a power $\lambda$ function (weights) based on positions of actors as references. Yet, referring to the political economy bargaining theory of Zusman (1976) for detail, it can come to an analytical solution of the above problem. In particular Zusman put emphasis on setting alternatives (references in Diagram 4) done as pairwise comparison. Usually, an outline on bargaining modelling is very theoretical. But such models offer simulations for compromises as dependent on variations in government regulations and institution.

As it is observable in Diagram 4, we need cooperation. Bargaining starts from a limited allocation of property rights (as opposed to a market solution of full rights) and it depicts power relationships involved in cooperative games. To reveal more of the theoretical background, note power and weighted cooperative actions (not social welfare) are derived from individual interests (prepared above). In cooperative games (Harsanyi 1993) a solution is offered where contracts (parameters) are endogenous. In particular, we need corner solutions to establish the 
slope $\lambda$ which is the power indicator and which serves for weighting interests. Corners are established by alternatives. Interest creation is broadly defined as: (i) "maximizing net gains from cooperation"; and (ii) cooperation with one marketing unit reduces cooperation with the other (a perspective of individual producers as well as links to markets by broker and the FSA, a "driving force" for cooperation becomes into play). This is enough for a construction of a joint welfare function (not a social one). This "welfare function" (19) is a weighted one.

In practice, negotiations (either of the broker/retailer and farmer for premium meat without antibiotics on sharing or of FSA and farmer for compensation for reduced stocking) are conducted based on knowledge of reference points gained in negotiations. They are chosen by producers mutually. Producers depict (know) choices with alternative trading partners entering new ones. Hereby, we see a similarity to Zusman, 1989. Finally power coefficients are calculated, given reference points for an ultimately explained situation of a Nash game. The crucial point is that such political bargaining models work along exchange of contractual parameters.

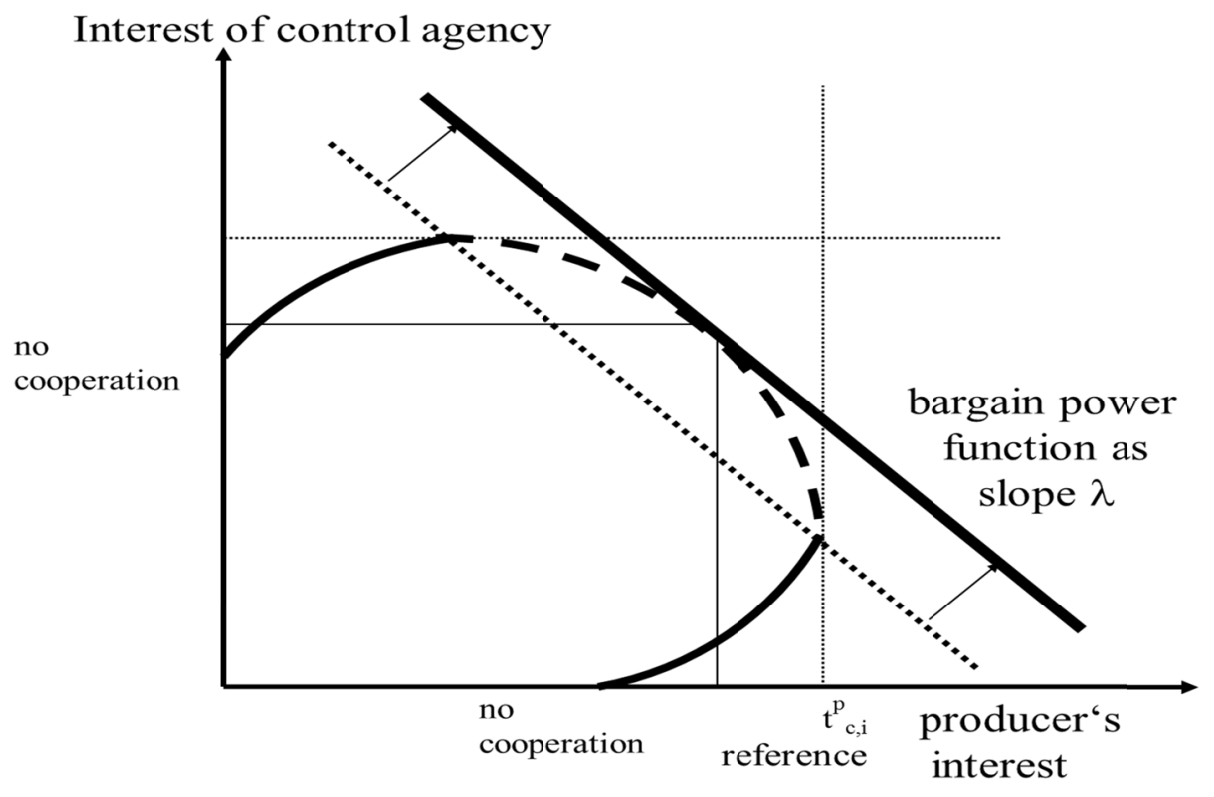

Diagram 4. Political bargain model and power measurement 
Diagram 4 illustrates how power coefficients for "social welfare" are assembled as lines.

$$
W=\left[\sum_{i} \Pi_{i}\right]+\theta_{B} B+\theta_{A} A
$$

additionally: $\theta_{\mathrm{i}}$ : power coefficients of $A$ agency and $B$ broker: The power of producers is $\left(1-\theta_{A^{-}}-\theta_{B}\right.$

Such "social welfare function (19)" is technically obtainable; it is endogenous to the bargaining, not assumed. Power is given by the slope of the diagonal which intersects corner solutions in modelling of reference points for bargaining (given different initial rights as in a principal agent model). Partial optimization means slopes are zero for corners. If FSA has the right to set terms for a contract as a principle and a producer is an agent, we have the upper left corner and vice versa we have lower left corner. Finally, the result is a public "societal welfare function" which is optimized (Zusman, 1989). The optimization itself is thorny. Still, the important task here was to show how to find power coefficients. In other words, the crucial thing is to determine references in bargaining which can be done using the above interest functions.

To finally comment, there is no simple version of an institution which guarantees a social optimum per se; rather in case of collusion bargaining is a way. We have to work with second best institutions in reality; though it is feasible to find improvements. Lastly scenarios of bargaining, as in case of Zusman's marketing models, can be delineated and they are bilateral negotiations with references, constituted by marketing opportunities and governance (minimum standards on antibiotics). Hereby government can take an indirect position in creating power for the agency FSA. The proposition is: Bargaining equilibriums can be established which are superior to no-cooperation; i.e. selling of meat to corresponding market segments or alternatives is a partial solution and it is welfare improving. Those who have worked with Zusman (1989) know it is challenging to get drafts, but we can get it with mathematical procedures.

\section{Summary and Discussion}

This paper has developed a framework for bargaining on stocking density in the meat industry which is voluntary and aiming at reducing antibiotics use in case of economies of scale. It is involving marketing options and power. For this we developed a new institutional setup which is (i) based on existing literature of bargaining. It was argued that stocking density and antibiotics are correlated. (ii) Then we looked at market segmentation as option to stimulate interest in reduction of stocking density, i.e. in a cooperative game frame. (iii) As potential actors to negotiate with producers on stocking density, we introduced a broker (linked to retailing) and an agency (FSA) which, on behalf of a government, compensates farmers for not fully exploring economies of scale (stocking density). We elaborated on how to create interests by using market choices, share premiums and get compensation. It has been developed for markets with discretionary choices of farmers (market channels) and intermediaries (brokers \& agency) and it is applied to the case of a meat industry. (iv) Then we showed how interest functions can be carved formally to obtain a game which can be and is partly mathematically presented.

Finally, we suggested how to proceed in a mathematical formulation and explained that the suggested frame fits into existing bargaining concepts such as those of Zusman, (1989). As a result of the paper we can say that there is scope to think about creating private and semi-autonomous institutions for reducing stocking density and antibiotics use in meat industries. A test would be whether stocking density works as agreeable proxy. As remark on stocking and negotiating parameters, alternatively one can think about an index comprising several other, weighed measures (changes: Agrarheute, 2014). This would imply making further agreements and control of measures and weights. Also, alternatively there are suggestions about differently financing a FSA (by surcharge for better images of meat), then from retailers (Germany: QS, 2013b; however this is not explored in this contribution, though feasible to model). It implies that FSA works similar, but cost-benefits change. The problem is then to re-specify WTP as public and private? It increases complexity, but is feasible. Especially the issue of transaction cost minimization should be further considered in searching for alternatives to govern the meat industry for health reason. One next task, for food safety policy research, would be to obtain simulations on likely parameter and link them to derivations from practice in bargains.

\section{References}

Agrarheute. (2014). Tierwohlinitiative: Erste Details bekannt. Retrieved from http://www.agrarheute.com/tierwohl-initiative-details. Internet accessed: 08.01.14.

Alanis, A, J. (2005). Resistance to Antibiotics: Are We in the Post-antibiotic Era? Archives of Medical Research, 36, 697-705. http://dx.doi.org/10.1016/j.arcmed.2005.06.009

Archie, E. A., \& Theis, K. (2011). Animal behaviour meets microbial ecology. Animal Behaviour, 82, 425-436. 
http://dx.doi.org/10.1016/j.anbehav.2011.05.029

Bailey, A.P., \& Garforth, C. (2014). An industry viewpoint on the role of farm assurance in delivering food safety to the consumer: The case of the dairy sector of England. Food Policy, 45, 14-24. http://dx.doi.org/10.1016/j.foodpol.2013.12.006

Carlson, F., Frykblom, P., \& Lagerkvist, C. J., (2007). Consumer willingness to pay for animal welfare: mobile abbatorirs versus transportation to slaughter. European Review of Agricultural Economics, 34, 321-344. http://dx.doi.org/10.1093/erae/jbm025

Chantziaras, I., Boyen, F., Callens, B., \& Dewulf, J. (2014). Correlation between veterinary antimicrobial use and antimicrobial resistance in food producing animals. A report on seven countries. Journal of Antimicrobial Chemotherapy, 69, 827-834. http://dx.doi.org/10.1093/jac/dkt443

Coase, R., H. (1960). The problem of social costs. Journal of Law and Economics, 2, 1-44. http://dx.doi.org/10.1086/466560

Deckers, J. (2010). Should the consumption of farmed animal products be restricted, and if so, how much? Food Policy, 35, 97-503. http://dx.doi.org/10.1016/j.foodpol.2010.06.003

Deutscher, B. (2013). Bundesrat verabschiedet Arzneimittelgesetz: DBV warnt vor mangelhafter Praktikabilität und viel Bürokratie $\quad$ Retrieved from http://www.bauernverband.de/bundesrat-verabschiedet-arzneimittelgesetz. Press-Information, accessed: 05.07.2013

Deutsche, B. (2014). Initiative Tierwohl geht an den Start. Brochure.

Die, Z. (2014). Tiermedizin Dauernd Stoff vom Arzt. Retrieved from http://www.zeit.de 2014/49/antibiotika-im-fleisch-tiermedizin

Eden, S., Bear, C., \& Walker, G., (2008). Understanding and (dis)trusting food assurance schemes: consumer confidence and the 'knowledge fix'. J. Rural Stud, 24, 1-14. http://dx.doi.org/10.1016/j.jrurstud.2007.06.001

Estevez, I., Andersen, I.-L., \& Naevdal, E. (2007). Group size, density and social dynamics in farm animal. Applied Animal Behaviour Science, 1003, 185-204. http://dx.doi.org/10.1016/j.applanim.2006.05.025

Fels-Klerx, H. J. V. D., Puister-Jansen, L. F., Asselt, E. D. V., \& Burgers, S. L. G. E. (2014). Farm factors associated with the use of antibiotics in pig productions. Journal of Animal Science, 89(6), 1922-1929. http://dx.doi.org/10.2527/jas.2010-3046

Furubotn, E. G., \& Richter, R., (2005). Institutions and Economic theory. The Contribution of the New Institutional Economics (2nd ed., p. 653). Ann Arbor: The University of Michigan Press.

Garforth, C., Bailey, A., \& Tranter, R. (2013). Farmers' attitudes to disease risk management in England: a comparative analysis of sheep and pig farmers. Prev. Vet. Med, 110, 456-466. http://dx.doi.org/10.1016/j.prevetmed.2013.02.018

Goodwin, J. N., \& Shoulders, C. W. (2013). The future of meat: A qualitative analysis of cultured meat media coverage. Meat Science, 95, 445-450. http://dx.doi.org/10.1016/j.meatsci.2013.05.027

Harsanyi, J. C. (1993). A simplified bargaining model for the n-person cooperative game. International Economic Review, 4(2), 194-220.

Korzen, S., Sandoee, P., \& Lassen, J. (2011). Pure meat - Public perceptions of risk reduction strategies in meat production. Food Policy, 36(2), 158-165. http://dx.doi.org/10.1016/j.foodpol.2010.10.005

Lindgreen, A. (2003). Trust as a valuable strategic variable in the food industry: Different types of trust and their implementation. British Food Journal, 105(6), 310-327. http://dx.doi.org/10.1108/00070700310481694

Lusk, J. L., Norwood, F. B., \& Pruitt, J. R. (2006). Consumer demand for a ban on Antibiotic Drug Use in Pork Production. American Journal of Agricultural Economics, 88(4), 1015-33. http://dx.doi.org/10.1111/j.1467-8276.2006.00913.x

Lusk, J. L., \& Norwoord, F.B. (2012). Speciesism, altruism and the economics of animal welfare. European Review of Agricultural Economics, 39(2), 189-212. http://dx.doi.org/10.1093/erae/jbr015

Loo, E. J. van, Caputo, V., Nayga, R. M. (jr.), \& Verbeke, W. (2014). Consumers' valuation of sustainability labels on meat. Food Policy, 49(1), 137-15. http://dx.doi.org/10.1016/j.foodpol.2014.07.002

Meat.Org. (2013). Retrieved from http://www.meat.org/ video 
Myerson, R. (1991). Game Theory: Analysis of Conflict. (p. 569) Harvard University Press Cambridge, MA., First Harvard University.

Ngapo, T. M., Dransfield, E., Martin, J.-F., Magnusson, M., Bredahl, L., \& Nute, G. R. (2004). Consumers perceptions: pork and pig production. Insight from France, England, Sweden and Denmark. Meat Science, 66(1), 125-134. http://dx.doi.org/10.1016/S0309-1740(03)00076-7

Niskanen, W. A. (1971). Bureaucracy and representative government. New Jersey.

Ollinger, M., MacDonald, J. M., \& Madison, M. (2005). Technological Change and Economies of Scale in U.S. Poultry Processing. American Journal of Agricultural Economics, 87(1), 116-129. http://dx.doi.org/10.1111/j.0002-9092.2005.00706.x

Oude Lansink, A., \& Reinhard, S. (2004). Investigating technical efficiency and potential technological change $\begin{array}{lllll}\text { in Dutch pig farming. } & \text { Agricultural }\end{array}$ http://dx.doi.org/10.1016/S0308-521X(03)00091-X

QS. (2013a). Retrieved from http://www.q-s.de

QS. (2013b). Mehr Tierwohl in der Schweine- und Geflügelwirtschaft. Pressemitteilung. Press Release Accessed 05.09.13. QS Qualität und Sicherheit GmbH.

Pew Commission. (2009). On Industrial Farm Animal Production. Retrieved from http://www.ncifap.org/

Rausser, G., Swinnen, J., \& Zusman, P. (2011). Political Power and Economic Policy. Theory, analysis and Emprical Apllications (p. 624). Cambridge: Cambridge University Press. http://dx.doi.org/10.1017/CBO9780511978661

Requillart, V., \& Soler, L-G. (2014). Is the reduction of chronic diseases related to food in the hands of the food industry? European Review of Agricultural Economics, 41(3), 375-403. http://dx.doi.org/10.1093/erae/jbu010

Rushen, J. (2003). Changing concepts of farm animal welfare: bridging the gap between applied and basic $\begin{array}{lllll}\text { research. Applied Animal Behaviour } & \text { Science, } & \text { 81, } & \text { 199-214. }\end{array}$ http://dx.doi.org/10.1016/S0168-1591(02)00281-2

Seals, M. (2012). Developing a Government-Industry Partnership on Animal Health and welfare Policy in England. Eurochoices, 11(2), 45-48. http://dx.doi.org/10.1111/j.1746-692X.2012.00234.x

Soerensen, J. T., \& Fraser, D. (2010). On-farm welfare assessment for regulatory purpose: Issues and possible solutions. Livestock Science, 131, 1-7. http://dx.doi.org/10.1016/j.livsci.2010.02.025

Tilman, D., Cassman, K. G., Matson, P. A., Naylor, R., \& Polasky, S. (2002). Agricultural Sustainability and intensive production practices. Review Article. Nature, 418, 671-677. http://dx.doi.org/10.1038/nature01014

TAZ. (2013). Fleisch aus Massentierhaltung: Ein Siegel für mehr Stallfläche. Retrieved from http://www.taz.de/Antibiotikum-im-Grundwasser/!149216/ accessed 12.03.15

Tonsor, G. T., \& Wolf, C. A. (2011). On mandatory labelling of animal welfare attributes. Food Policy, 36, 430-437. http://dx.doi.org/10.1016/j.foodpol.2011.02.001

Top Agrar online. (2013a). Bundesrat verabschiedet neues Arzneimittelgesetz. Retrieved from http://www.topagrar.com/news/Home-top-News-Bundesrat-verabschiedet-neues-Arzneimittelgesetz-11922 20.html

Top Agar online. (2013b). Erste Details zur Initiative Tierwohl bekanntgegeben. Retrieved from http://www.topagrar.com/news/Home-top-News-Erste-Details-zur-Initiative-Tierwohl-bekanntgegeben-124 5739.html

Top Agar online. (2015). Tierwohl-Initiative: Das sind die Kriterien für die Teilnahme . Retrieved from http://www.agrarheute.com/tierwohl-initiative-das-sind-die-kriterien-fuer-die-teilnahme.

Top-Agrar. (2012). Antibiotika-Studie: Hat Remmel Betriebe mit Hähnchen verwechselt? Retrieved from http://www.topagrar.com/news/Home-top-News-Antibiotika-Studie-Hat-Remmel-Betriebe-mit-Haehnchenverwechselt-710715.html, accessed 082.12.12

Torre, A. de la, Iglesias, I., Carballo, M., Ramírez, P., \& Muñoz, M. J. (2012). An approach for mapping the vulnerability of European Union soils to antibiotic contamination. Science of the Total Environment, 414, 672-679. http://dx.doi.org/10.1016/j.scitotenv.2011.10.032 
Vanhonacker, F., Verbeke, W., Van Poucke, E., Buijs, S., \& Tuyttens, F. (2009). Societal concern related to stocking density, pen size and group size in farm animal production. Livestock Science, 123, 16-22. http://dx.doi.org/10.1016/j.livsci.2008.09.023

Wegener, H.C. (2001). Antibiotics in animal feed and their role in resistance development. Current Opinion in Microbiology, 6, 439-445. http://dx.doi.org/10.1016/j.mib.2003.09.009

Zusman, P. (1989). Peasants' Risk Aversion and the Choice of Marketing Intermediaries and Contracts: A Bargaining Theory of Equilibrium Market Contracts. In P. Bardahn (Ed.), The Economic Theory of Agrarian Institutions (pp. 297-310). Oxford. http://dx.doi.org/10.1093/0198287623.003.0015

Zusman P. (1976). The incorporation and measurement of social power in economic models. International Economic Review, 7(2), 447-462. http://dx.doi.org/10.2307/2525712

\section{Copyrights}

Copyright for this article is retained by the author(s), with first publication rights granted to the journal.

This is an open-access article distributed under the terms and conditions of the Creative Commons Attribution license (http://creativecommons.org/licenses/by/3.0/). 